
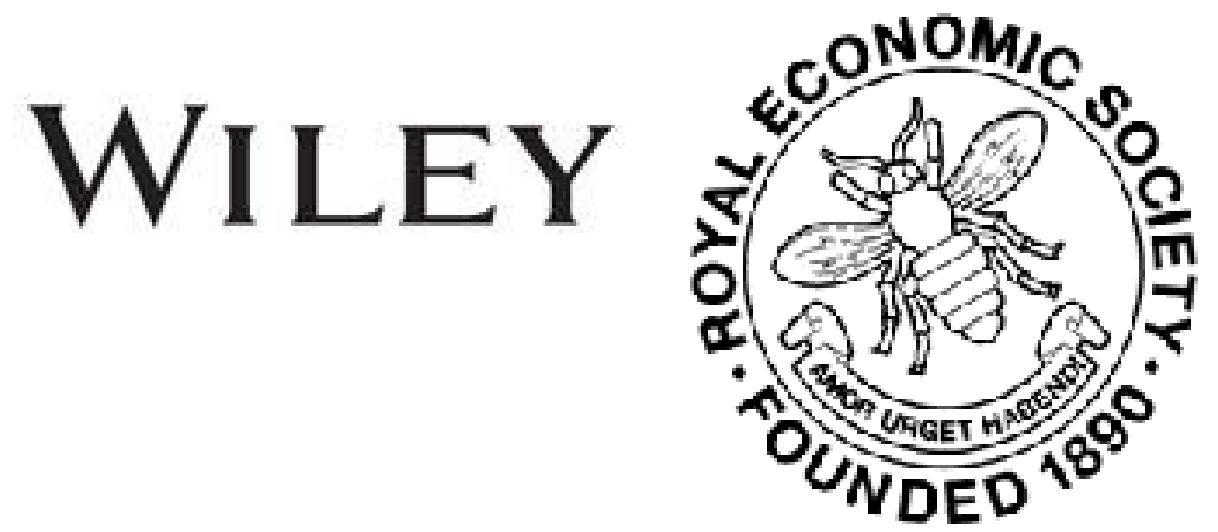

Token Money in Turkey

Author(s): F. W. Hirst

Source: The Economic Journal, Vol. 7, No. 25 (Mar., 1897), pp. 109-111

Published by: Wiley on behalf of the Royal Economic Society

Stable URL: http://www.jstor.org/stable/2956970

Accessed: 27-06-2016 01:17 UTC

Your use of the JSTOR archive indicates your acceptance of the Terms \& Conditions of Use, available at

http://about.jstor.org/terms

JSTOR is a not-for-profit service that helps scholars, researchers, and students discover, use, and build upon a wide range of content in a trusted digital archive. We use information technology and tools to increase productivity and facilitate new forms of scholarship. For more information about JSTOR, please contact support@jstor.org.

Wiley, Royal Economic Society are collaborating with JSTOR to digitize, preserve and extend access to The Economic Journal 
women hardly earn sufficient to keep body and soul together. The young girls almost without exception were thin, anæmic, and so overtired that even the unwonted excitement of appearing before the Commission could hardly rouse them, though they seemed to feel the questions relating to morality. Tuberculosis, various forms of indigestion, diseases of the eye and skin are rife among them. Deformities are also common, girls being put to hard work-such as turning heavy machinery, carrying heavy loads, \&c.-when they are still growing. At the brick-works I have seen young children, who were not even old enough to go to school, helping their parents by carrying heavy bricks for hours daily. When I first came to Vienna I was struck at the unusual number of dwarfs, hunchbacks, and cripples one meets during the day. On the day of my arrival I noticed near the Reichsrath a woman and dog drawing a heavy cart, while the man of the party walked on the pavement, smoking a pipe-a significant sight.

It seemed almost a mockery to ask the women what they did with their spare time. The Commissioners soon ceased putting the question. It is generally considered that by keeping the women hard at work, it will keep them out of mischief, and prevent them from "gadding about." Many of the women and girls have never been in a theatre. A few girls had saved money in order to go to one of the cheap Sunday afternoon performances.

The measures suggested at present by the Commission to remedy the evils described are :

(1) The appointment of a sufficient number of factory inspectors, and the inclusion of a certain number of women in their number ; and

(2) The establishment of trade societies for women.

The enquiry has aroused great interest in Vienna, an interest which it is to be hoped will be maintained, and in consequence of it, many employers have already granted small concessions to their workwomen. On the other hand, a few women who were suspected of giving evidence have lost their employment. What the actual result of the Frauen-Enquête will be lies with the future; but the members of the Commission will strain every nerve to bring about some permanent benefit, and this at no far distant date, to the women working in Vienna under conditions which a plain statement describes more eloquently than many adjectives.

A. S. Levetus

\section{Token Money in Turkey}

The theory of token money is illustrated by the late Professor Walker as follows. "Suppose," he asks, " billon or token-money to be issued in excess of the real requirements of trade, what will happen?" A quotation from Sir William Hunter's Annals of Rural Bengal shows 
that the tendency of copper coins to accumulate in the district treasuries still forms a subject of frequent official correspondence, and that a percentage is actually, in some places, allowed to the collectors of the assessed taxes in order to compensate them for the loss which results from converting the copper payments into rupees.

Another cutting is from Professor Sumner's History of the American Currency, where it is stated that the issue of the so-called " fractional" currency "was forced up to between $\$ 40,000,000$ and $\$ 50,000,000$, producing a redundancy and enhancing retail prices." In this second case, however, Professor Walker learns that no discount on the token money was submitted to by the retail dealers. That being so, he very properly declines to believe in the rise of retail prices.

The general answer, therefore, given by the late Professor Walker is that when an issue of "billon" becomes so excessive that those who receive it in trade find it hard to get rid of, and are com. pelled to submit to a discount, then, but not till then, there results a rise of retail prices which will press heavily on the poor, who cannot get a corresponding rise in their wages. It strikes me as a little strange that the theory should have been left incomplete; that the American economist, after a satisfactory analysis of the case where token-money is coined in excess, completely overlooks the other aspect of the question.

If there can be too much token-money there can also be too little. But the latter alternative is neglected for the natural enough reason, I suppose, that no Government in its senses would possibly be supposed to have an interest in at once cutting off from itself a legitimate source of profit, and at the same time causing great inconvenience to the public in general and to middlemen in particular. The omission illustrates the prevalence of the historical view. If experience had solved half the problem for Ricardo, Ricardo would have hypothesised the other half and predicted the consequences.

The Sultan's Government, however, realising the present decadence of the human intellect, has conducted the necessary experiment. The Finance Minister has discovered that a corner can be made in small change. The Mint officials are apparently in conspiracy with the money changers, and while the former keep the supply of "billon" below the demand for it, the money changers find themselves able to charge a discount, not, as in the Indian example, on the small money, but on the large. Out of this profit a small gratuity goes back to the Government officials.

For the details of this remarkable little " corner" I have to thank a special correspondent of the Leeds Mercury, from whose article in the issue of February 3rd I take the following extract:-

The Government has created a corner in small change by coining an insufficient quantity, with the result that one always loses a small sum every time one changes any of the larger coins. This state of affairs has created the very profitable business of money-changing. The Government 
works hand in hand with these money-changers by refusing to give change at all offices, bridges, \&c., so that the public are compelled to have recourse to the changer, who naturally pays a small gratuity to the officials in charge for the privilege of living near the office in question, and who also buys up from these officials the small change they collect. Owing to this fact the silver piastre which we have mentioned as the real unit on which the larger silver coins are based, is itself also a fictitious coin. For the actual silver one piastre piece is at a slight premium as small change.

Working out the results one may predict a fall in retail and a rise in wholesale prices, by which all employers will lose and all those who receive regularly small fixed payment will gain. If it be true that custom is, throughout the Turkish Empire, the chief factor in wages, the new currency experiment ought to be a boon to the labouring classes. We may yet live to see the method now on trial at Constantinople generally recognised by democratic finance ministers and adopted from time to time to effect the better distribution of wealth!

F. W. Hirst

\section{The Silver Question in the United States of America}

The present condition of the currency in America is in every particular the strictly logical outcome of our monetary policy for the last two decades. While all those European countries with which our commerce is most direct and most extensive, have closed their mints against silver, and have come to what, under one guise or another, is or approximates to gold monometallism, America, on the other hand, has shown a great fondness for silver. Through the limited but extensive coinage of dollars under the Bland Bill in the years 1878-1890 (\$378,166,793), and through the purchase of bullion for " treasury notes" under the Sherman Law in the years 1890-1893 (\$155,931,002), she has taken into monetary use as full legal tender above $\$ 500,000,000$ in silver. During this same period, 1878-1896, she has coined about $\$ 850,000,000$ in gold, the amount of the legal tender state notes, or " greenbacks," has remained unchanged, and the amount of the outstanding national bank-notes has decreased by only about $\$ 100,000,000$. The result of all this has been that her circulating medium of exchange has increased with great rapidity, has, in fact, doubled. This increase has, indeed, been not nearly so rapid as the expansion of the commerce of the country; but it has been much more rapid than any European country can show. Consequently, general prices have fallen here more slowly than in Europe ; and, under the familiar working of Gresham's Law, gold, our only exportable money, has tended to flow toward Europe. While, under the regime of the Bland Bill, the injection of silver into the circulation was only $\$ 30,000,0 \mathrm{CO}$ a year, and while at the same time America was a favourite field for European investors, there was no permanent out-flow. This country, after sixteen years' experience of incon- 